\title{
The Grotesque in Frankenstein in Baghdad: Between Humanity and Monstrosity
}

\author{
Rawad Alhashmi \\ The University of Texas at Dallas, $\boldsymbol{U S A}$ \\ rya140230@utdallas.edu
}

DOI: https://doi.org/10.36892/ijlls.v2i1.120

\begin{tabular}{|c|c|}
\hline $\begin{array}{l}\text { Received: } \\
\text { 13/01/2020 }\end{array}$ & $\begin{array}{l}\text { Abstract } \\
\text { This paper analyzes Ahmed Saadawi's Frankenstein in Baghdad (2018) with a }\end{array}$ \\
\hline $\begin{array}{l}\text { Accepted: } \\
\text { 17/03/2020 }\end{array}$ & $\begin{array}{l}\text { special emphasis on the grotesque bodily images of the monster, the novel's } \\
\text { exploration of justice, and the question of violence. I draw on the theoretical } \\
\text { framework of the Russian philosopher and literary critic Mikhail Bakhtin } \\
\text { (1895-1975), the ethics philosopher Emmanuel Levinas (1906-1995), and the }\end{array}$ \\
\hline $\begin{array}{l}\text { Keywords: } \\
\text { Dystopia; } \\
\text { Frankenstein; } \\
\text { Grotesque; Justice; } \\
\text { Monster; Other; } \\
\text { Violence }\end{array}$ & $\begin{array}{l}\text { German-American philosopher and political thinker Hannah Arendt (1906- } \\
\text { 1975). Saadawi's unnamed monster, "The Whatsitsname," comes into being } \\
\text { via an accidental if honorably intentioned act, when the main character, Hadi, } \\
\text { compiles remnant corpses that he finds in the streets of Bagdad into one body } \\
\text { with the aim of conducting "a proper burial" in order to dignify the dead. } \\
\text { Interestingly, while the monster is the enemy in the eyes of the Iraqi } \\
\text { government, he is a savior for the ordinary people - their only hope of putting } \\
\text { an end to the violence and achieving justice. In this paper, I argue that } \\
\text { Saadawi draws on the metaphor of Frankenstein's monster not only to capture } \\
\text { the dystopian mood in post-2003 Baghdad, but also to question the tragic } \\
\text { realities, and the consequence of war, as well as the overall ramification of } \\
\text { colonialism. In addition, Saadawi's embodiment of the metaphor of } \\
\text { Frankenstein's monster actualizes a new literary role for Frankenstein in } \\
\text { literature-the representation of the Other: In this instance, the entire Iraqi } \\
\text { community is literary represented in Frankenstein's body. Of equal } \\
\text { importance, is the fragmented nature of his body, which is literally compiled } \\
\text { of different body parts from different people, perhaps symbolizing the urgent } \\
\text { needfor unity in Iraq. }\end{array}$ \\
\hline
\end{tabular}

\section{INTRODUCTION}

Ahmed Saadawi's Frankenstein in Baghdad won the International Prize for Arabic Fiction in 2014. It is worth mentioning that this is the first time an Iraqi novelist has received this prestigious award. Saadawi constructs a powerful story, capturing the bitter reality of the current state of affairs throughout Iraq. He paints horrific images of wars, terrorist attacks, kidnappings, suicide bombings, and improvised explosive devices that ravage the streets of the capital city. Death is roving the streets of Baghdad, hunting people randomly and tearing families apart. Due to the spiraling cycle of violence, people's deaths have become mere statistics. In this context, Annie Webster (2018) argues that Saadawi's novel "confronts readers with the body parts of Iraqi civilians who did not survive the violence that permeated post 2003 Iraq and whose remains, left unidentified and unburied on the streets of Baghdad, do not seem to be valued" (p. 445). This speaks to dystopia that describes a real as opposed to an imaginary place. In other words, the dystopian aspects of the novel stem from a gruesome but actual 
world-Baghdad after 2003. In this manner, Saadawi's work portrays an existent dystopia, as argued by Fatima Vieira (2010): "Thus, the word dystopia came into usage not only to refer to imaginary places that were worse than real places, but also to works describing places such as these" (p. 17 [italics added]).

Saadawi's historical and artistic context is deeply rooted in his tradition-his Arabic heritage, which is characterized by a profound poetic style and rich narrative.i Yet, his source of inspiration is not fixed only on the Arabic tradition. He also is greatly influenced by many Western writers, including but not restricted to "Borges and English and French fantasy writers such as H. G. Wells and Jules Verne" (Becker, 2018, para. 6). Saadawi claims that he is not only inspired by Mary Shelley's Frankenstein, and also "the vast cultural space that is called "Frankenstein," (Najjar, 2014). This suggests that what influenced Saadawi is the legacy of Frankenstein and its metaphorical importance in general, as he "was a massive fan of the 1994 film Mary Shelley's Frankenstein" (Hankir, 2018). Thus, Saadawi draws on the Frankensteinesque, yet the latter is closely connected with the status quo in Iraq.

Notably, Frankenstein in Baghdad, as the name indicates, draws upon Mary Shelley's Frankenstein; or, The Modern Prometheus (1818). It is worth noting that the English version of Frankenstein in Baghdad came out on the 200th anniversary of the publication of Shelley's novel. Interestingly, Saadawi's novel is the first Arabic work that adopts the metaphor of Frankenstein. However, Saadawi's monster wears a new fashion that makes it distinct from that of Shelley's, particularly in terms of its creation and quest. Nevertheless, they share a common theme - revenge. The creation of Dr. Frankenstein's monster was intentional and brought about by electric jolts to the bolts in his neck for the sake of pride based on a scientific invention, whereas that of Hadi was coincidental and constructed artistically through a surreal sense for the sake of "a proper burial" (Saadawi, 2014, p. 24). Put succinctly, while the creation of the original Frankenstein is based on curiosity, Saadawi's Whatsitsname is a miraculous creation.

More importantly, the original Frankenstein's body is comprised of animal and human parts while Hadi's Frankenstein is made only of human body parts. The Whatsitsname stresses that: "I was careful about the pieces of flesh that were used to repair my body. I made sure my assistants didn't bring any flesh that was illegitimate - in other words, the flesh of criminals" (Saadawi, 2014, p. 156). Furthermore, what generates the monstrosity in Shelley's Frankenstein is the rejection of Dr. Victor Frankenstein of his creation and the monster's subsequent isolation, which, in turn, triggers his revenge. That is to say, his isolation is imposed upon him because the people he tries to befriend all turn on him out of fear and ignorance. Thus, Shelley's Frankenstein deals with themes of the Other and Otherness in relation to the monster himself - eventually, the monster's inhumanity separates him from humankind. Due to his xenophobia, he is involuntarily made into an isolated Other. Saadawi's monster, in contrast, is accepted as a hero in the eyes of ordinary people and deemed as a criminal by the Iraqi government. While Shelley's Frankenstein avenges himself, Saadawi's Whatsitsname takes revenge on behalf of (for the sake of) other victims. Hence, his quest for vengeanceii is about the others from whom his body is composed, insofar as the creature is "made up of the body parts of people who had been killed, plus the soul of another victim ... He was a composite of victims seeking to avenge their deaths so they could rest in peace" (Saadawi, 2014, p. 130). Thus the two monsters' unique motivations stem from both internal and external sources.

Indeed, Frankenstein in Baghdad represents dreadful realities to the world, insofar as it depicts authentic experiences by unfolding what is happening artistically through speculative lenses and thereby goes beyond the media depiction of reality. Saadawi himself used to work as 
a reporter for the BBC Arabic channel in 2006, covering violence and war in occupied Iraq that was violently destroying his country. "I saw many dead bodies," Saadawi reports, "not just dead bodies - body parts. Many body parts" (Hankir, 2018). After working as a reporter and witnessing horrific scenes, Saadawi opted to convey his experience through artistic ink, capturing the manifold nuances of violence and terror. Moreover, he seeks to reflect the aesthetic qualities through fictional writing by revealing his creative account that extrapolates from reality and conveys it through a dystopian narrative. In Saadawi's words, "I do hope English readers will enjoy it as a work of art. But also that it will be a chance for them to find out about Iraq and through the eyes of a local writer, beyond Baghdad what appears in the media or in news coverage" (East, 2018 para. 5). Saadawi's magnum opus mirrors his artistic vision of reality through surreal lenses. In the same vein, Tim Arango (2014) argues that, "[t]he novel reflects Mr. Saadawi's belief that fiction is better suited than journalism and memoirs to convey the full emotional experience of living in a city where extraordinary levels of violence have become ordinary."'iii Here, Saadawi presents a creative gift to the world, capturing the diffusion of violence that contaminates the environment of Iraq's capital in post 2003.

In fact, Saadawi emphasizes the importance of fiction writing as a means of personal expression that goes beyond non-fiction. In his words, "[w]riting, especially novel writing, became my identity" (Becker, 2018, para. 2).iv Additionally, his motive for writing fiction manifests "a sense of responsibility toward matters of public interest and the possibility that art and literature can to some extent change the way readers think" (Becker, 2018, para. 3). Saadawi chooses dystopian narrative to reflect his artistic efforts to capture unstable social and political conditions of a local scene.v In doing so, his fantastic narrative reveals a new aesthetic dimension due its ability to underscore the connection between the personal and political climate in the country.vi Thus, he intentionally translates his account of social and political changes to reveal everyday experience.

In his novel, Saadawi employs the grotesque both artistically and realistically in order to convey the horrifying situation and the waves of violence that erupted in the capital city of Iraq in post-2003. As he has pointed out in his interview in The National, "[p]eople with logical minds understand the need for imagination in times of crisis and violence" (East, 2018, para. 9). In fact, the grotesque emerges when the real and the fantastic elements meet in one milieu. As per Mikhail Bakhtin (1895-1975), "the grotesque starts when the exaggeration reaches fantastic dimensions" (1984, p. 315). Saadawi's work exemplifies this element, offering him an imaginative space to create his monster, unraveling the explosion of violence and horror. For Saadawi, fantasy is a paramount element in the dystopian narrative, inasmuch as "[i]t gives vitality and brings out the overwhelming imaginative powers of writing. But there is a deeper reason for me [Saadawi]. The Iraqi society itself has created permanent forms of fantasy-and treats them as facts" (East, 2018 para. 7). Hence, in this situation, the feature of the grotesque image conveys not only the fantastic or surreal aspects, but also the real scenes of decay and horror as well, particularly in the aftermath of the American led invasion of Iraq. According to Hani Elayyan (2017, p. 159), Frankenstein in Baghdad "tells the story of the violence that erupted after the occupation and seeks to investigate the reason for the increase in violence and terrorism in the years that followed the occupation." Elayyan suggests that the American led invasion of Iraq in 2003 resulted in chaos and violence like that of the most destructive dust storm that swept out throughout Iraq, leaving in its wake, fear, violence, and terror.

More importantly, the manifestation of the grotesque body images of the Whatsitsname is directly related to all Iraqis. Such a collective image reflects the Iraqi society as a whole. Here 
the image of the people acquires a great significance through its manifestation of the Iraqi people in the Whatsitsname's body. Bakhtin (1984) notes, "[m]anifestations of this life refer not to the isolated biological individual, not to the private, egotistic 'economic man,' but to the collective ancestral body of all the People" (p. 19 [italics added]). In this sense, the grotesque body image is representative of all people in Iraq and that is why the Whatsitsname in turn belongs to all of them. Actually, the image of the Whatsitsname reflects the pivotal point of the physical incarnation, as per Bakhtin's observation: "Grotesque images may, of course, present other members, organs and parts of the body (especially dismembered parts)" (1984, p. 318). This rings true in Saadawi's assertion of the grotesque images in the Whatsitsname. For Saadawi, the Whatsitsname "is the mirror image of us as a whole" (East, 2018, para. 12). As such, it explains the Whatsitsname's statement that inasmuch "[I am] made up of body parts of people from diverse backgrounds - ethnicities, tribes, races, and social classes-I represent the impossible mix that never was achieved in the past. I'm the first true Iraqi citizen" (Saadawi, 2014, p. 146-47). In this context, the Whatsitsname calls for the unity of all the Iraqi peoples, regardless of their various backgrounds and different ethnicities, in order that they reconcile, and thereby confront the dreadful realities and end the sectarian violence. The Whatsitsname states: "I'm the model citizen that the Iraqi state has failed to produce" (Saadawi, 2014, p. 146). Such a statement urges all Iraqi people to embrace their country and to unify under one flag, leaving behind all of the ramifications and problems that were caused by foreign occupations and wars, prompting them to look forward to an optimistic future - a new era of positive change by enacting unity, restoring justice, political reformation, and freedom.

Equally important, Saadawi is also concerned with the issue of Iraqi identity, especially when considered in light of the consequences of war and the ramifications of colonialism. He reveals his intention by stating that, "I wanted to shed light on several issues with this book ... One [issue] was the paradox of identity diversity in Iraq, and how people understand themselves. All my characters are from different backgrounds" (Hankir, 2019). This is essentially true in the novel wherein there are many characters of mixed races, who live in the Bataween District in the heart of Baghdad, the neighborhood where the novel's major events take place. This is also where the main character, Hadi, lives, and where the monster arises. The residents of the neighborhood include Abu Salim and his wife Umm Salim, Abu Anwar, Aziz the Egyptian, Faraj the realtor, and Elisha or Umm Denial, among others. In addition, Saadawi draws a fictional map, setting up his work in the Bataween area, using it as a central point in his artistic creation, as Roger Allen argues, "With regard to the treatment of place, for example, the city in the Arabic novel ... serves as the primary location" (1993, p. 216). Additionally, the characters of the novel are carefully chosen, as if Saadawi picked them right from the streets, insofar as the names, occupations, ethnicities, and roles (a journalist, a migrant worker, a junk dealer, a housewife, barber, and brigadier - the list goes on and on) depicted in the novel mirror the everyday life of Iraq.

While Saadawi's novel is mostly focused on the locals, especially those who live in the Bataween area, it shifts here and there to highlight the presence of a foreign force in Iraq, particularly the American army. As the narrator recounts in the following scene: "Hadi lay awake, looking up at the square of blue sky above and the birds darting past. He closed his eyes a while, then opened them again and caught sight of the silhouette of an American helicopter flying past, making a thunderous whacking noise" (Saadawi, 2014, p. 203). In this scenario, Saadawi refers to the existence of occupation in the backstage of his novel, depicting it as a "silhouette" of a colonial project. In other words, the shadow representation of the foreign force 
in the novel attests to the existence of occupation in Iraq, which, in turn, has added another level of complication into an already complicated situation - from the Baath party rule to a colonial condition - such an external factor directly impacts the internal local situation in many forms, including war and violence, leading to a fragmentation of the country. Saadawi implicitly highlights the colonial occupation in relation to the status quo and the prevalence of violence that comes with it.

\subsection{The Rise of the Whatsitsname}

Saadawi calls his monster Shesma, which in an Iraqi dialect means, "what's his name" or "the one who has no name;" hence, the rendering in English as translated by Jonathan Wright: "The Whatsitsname." Such a conveyance of the phrase into a compound name, yet with the signal word "the Whatsitsname," perhaps symbolizes the body of the creature, insofar as he is comprised of the corpses of many different people. In fact, the idea of collecting human corpses from the streets of Baghdad comes to Hadi, a junk dealer and an antique collector, when he loses his close friend, Nahem Abdaki, in the horrific explosion of "a car bomb" (Saadawi, 2014, p. 24). Nahem and his horse are killed and it is "hard to separate Nahem's flesh from that of the horse" (24). Indeed, this traumatic experience is devastating for Hadi, and the shock changes him (24). Therefore, Hadi decides to gather up each human corpse he finds in the streets so that "it wouldn't be treated like trash, so it would be respected like other dead people and given a proper burial" (Saadawi, 2014, p. 27). Evidently, what triggers Hadi in doing such a noble job is not only losing his best friend, but also his responsibility to honor the Other. Hence, after Hadi has completed an entire human body from the parts he finds scattered in the streets, the monster comes into being. Namely, Hadi stitches parts of the victims' bodies together to form one single body - which is then possessed by a soul and comes to life as a monster. That soul is Hasib, a hotel security guard who died by a suicide bombing. His spirit inhabits the corpse and the composite monster came into being.

\section{THE MONSTROSITY OF THE MONSTER}

The first attack of the Whatsitsname in the streets of Baghdad results in the killing of four beggars. Describing this preternatural crime, the narrator recounts, "[e]ach of the beggars had his hands around the neck of the man in front of him. It looked like some weird tableau or theatrical scene. Their clothes were dirty and tattered, and their heads hung forward" (Saadawi, 2014, p. 69). This horrific incident raises many questions about the perpetrator and generates fear among people in the city, insofar as the beggars are killed in such a peculiar way: "He [the Whatsitsname] had strangled, and then by some bizarre and complicated operation, he'd put their hands around each other's throat" (Saadawi, 2014, p. 79). Consequently, "[f]ear of the Whatsitsname continued to spread" (Saadawi, 2014, p. 268). News of the ghastly scene of the crime spreads everywhere in the city; people are terrified about such an uncanny crime scene. Therefore, "Everyone in the area had heard the story and the local people were afraid" (Saadawi, 2014, p. 79).

As the novel unfolds, the monster becomes a topic of daily conversation among people in the streets and coffee shops; he appears on television on the Iraqi government's "Most Wanted" list. The monster is charged with several dreadful crimes in the city:

People in coffee shops spoke of seeing him during the day and vied to describe how horrible he looked ... He's everywhere and has an amazing speed, 
jumping from roof to roof and wall to wall in the middle of the night, they added. No one knew who his next victim would be, and despite all the assurances from the government, people grew more convinced with every passing day that he would never die. (Saadawi, 2014, p. 268)

In other words, the monster or the "criminal X," as labeled by the Iraqi government becomes well known figure, appearing in the news almost on a daily basis, "[w]ith a caption stating reward for anyone who provided information leading to his arrest" (Saadawi, 2014, p. 209). After the killing of the beggars in this bizarre, tableau manner, Brigadier Majid takes over the case and commences his investigation. Brigadier Majid works in a secret department under American supervision, the Tracking and Pursuit Department, created in order to monitor and investigate strange accidents in the city as well as to even predict crimes that may take place in the future, such as "car bombings and assignation of officials and other important people" (Saadawi, 2014, p. 75). Therefore, Brigadier Majid and his assistants closely examine such strange crimes that spread in city, and their investigations point to a single perpetrator, as "in every crime there was one victim, and the victim had usually been strangled" (Saadawi, 2014, p. 111). To be more specific, the first report that comes to the brigadier from his assistants "spoke of ghostly figures gathering on the Imam Bridge" (Saadawi, 2014, p. 110). At first, Brigadier Majid is confused by this information and is even suspicious about these reports from his assistants, the fortune-teller and astrologer, but the final report confirms "the ghostly figures" behind all these bizarre crimes. Eventually, Brigadier Majid concludes that there is only one culprit behinds all these crimes. Then the senior astrologer informs him that "it's the One who has no name ... raising his arms in the air - a gesture that suited his flamboyant appearance: he had a long white pointed bread, a tall conical hat, and flowing robes" (Saadawi, 2014, p. 112). However, all the efforts of Brigadier Majid seem to be in vain. No additional progress is made on the case, insofar as he is unable to stop the explosions or apprehend the monster. Consequently, the Tracking and Pursuit Department is shut down and "Brigadier Sorour Majid was forced to retire" (Saadawi, 2014, p. 269). His inhumanity magnifies the very basic need of man to survive, and his fear of the unknowable.

Ultimately, the Whatsitsname is overwhelmed not only by sheer number of the criminals he feels compelled to chasten, but also by time. The narrator reveals: "Each piece of dead flesh that made up his body fell off if he didn't avenge the person it came from within a certain amount of time. But if he did avenge someone, then that person's piece would fall off anyway, as if it was no longer needed" (Saadawi, 2014, p. 134-35). Rather than restraining violence, he is preoccupied with his own survival instead. He then turns to killing people in order to extend his own life.

Clearly, his mission is eventually perverted by madness. After he takes revenge on all the murderers responsible for the deaths of victims whom his body parts comprises from, his body starts to dissolve, and he feels lost in the state of decay: "The Whatsitsname was now at a loss for what to do. He knew his mission was essentially to kill, to kill new people every day, but he no longer had a clear idea who should be killed or why. The flesh of the innocents, of which he was initially composed, had been replaced by new flesh, that of his own victims and criminals" (Saadawi, 2014, p. 200). Therefore, he ceases to distinguish between good and evil and starts killing anyone who catches his eyes. In other words, the distinction between innocent and guilty becomes blurred such that "the criminals and the victims are entangled in a way that is more complicated than ever before" (Saadawi, 2014, p. 214). Hence, the Whatsitsname's 
assignment ends with disgrace when he goes astray and ignores his responsibility towards the Other. As a result, he loses his humanity after he loses his morality and plunges into the abyss, wherein he starts killing to ensure only his survival, insofar as he has to replace his body parts constantly. For instance, the Whatsitsname tells one of his assistants, the old astrologer that his face keeps changing constantly. He goes further in the same conversation with his assistant and states that "Nothing in me lasts long, other than my desire to keep going. I kill in order to keep going.' He didn't want to perish without understanding why he was dying and where he would go after death, so he clung to life, maybe even more than others, more than those who gave him their lives and parts of their bodies-just like that, out of fear" (Saadawi, 2014, p. 267-68 [italics added]).

\section{THE GROTESQUE BODY IMAGE OF FRANKENSTEIN IN BAGHDAD}

The hybrid nature of the Whatsitsname allows him to easily detach any body part. This is yet another significant feature in terms of his grotesque bodily image. This phenomenon is perhaps best described by Bakhtin. According to him, "[ $\mathrm{t}]$ he grotesque body ... is a body in the act of becoming. It is never finished, never completed; it is continually built, created, and builds and creates another body" (1984, p. 317). This is essentially true of the Whatsitsname, wherein his body's components require continuous replacement in order for him to survive. In the Whatsitsname's words: "When I got up the next day, I found that many parts of my body were on the ground, and there was a strong smell of rot" (Saadawi, 2014, p. 148-49). Thus, the Whatsitsname needs his decomposed parts to be constantly replaced with new flesh in order to remain alive. As a result of such maintenance, his body transforms and changes accordingly. The body of the monster is never complete, insofar as it lives in the flesh of dead bodies and always needs replacement body parts. Bakhtin is again instructive on this point:

There is nothing completed, nothing calm and stable in the ... [grotesque]. They combine a senile, decaying and deformed flesh with the flesh of new life, conceived but as yet unformed. Life is shown in its two-fold contradictory process; it is the epitome of incompleteness. And such is precisely the grotesque concept of the body. (1984, p. 25-26)

This process also equates to the Whatsitsname's body, as he notices one day that his face has changed. That is, whenever he replaces his body parts, his face's features duly transform. The Whatsitsname remarks that: "My face changes all the time" (Saadawi, 2014, p. 267). This notion of transformation resonates in Bakhtin's statement: "The grotesque image reflects a phenomenon in transformation, an as yet unfinished metamorphosis, of death and birth, growth and becoming" (p. 24). Insofar as the monster survives through the renewal of his body parts from other dead bodies, the dead bodies' parts come alive when they are attached to those of the monster's, albeit only temporarily. That is why " $[\mathrm{t}]$ he grotesque images preserve their peculiar nature, entirely different from ready-made, completed being ... they are ugly, monstrous, hideous from the point of view of 'classic' aesthetics, that is, the aesthetics of the ready-made and the completed" (Bakhtin, 1984, p. 25). This image applies to the Whatsitsname, as he is an "extraordinary composite" (Saadawi, 2014, p. 53). Thus the monster reflects the mosaic of occupied place and people torn asunder by war.

Notably, in the grotesque body, the face is the most recognizable and the most important part of the human body, as it is the first thing that is used to identify a person. This notion of appearance in the form of the grotesque body is greatly emphasized by Bakhtin. He 
writes, "of all the features of the human face, the nose and mouth play the most important part in the grotesque image of the body; the head, ears, and nose also acquire a grotesque character when they adopt the animal form or that of inanimate objects" (1984, p. 315). Bakhtin suggests that the face is the part of the body wherein grotesqueness is most profoundly noticeable, and it acquires the characteristic of the grotesque when it manifests inhuman facial parts. Saadawi exhibits this image in the Whatsitsname, albeit differently. To clarify, when Hadi collects the body of the monster from dead bodies, he is careful to complete the entire body. The culminating addition is the nose: "The nose was all the corpse needed to be complete" (Saadawi, 2014, p. 26). In this scenario, Saadawi is so concerned about compiling the Whatsitsname's body only from human body parts - unlike Bakhtin's thoughts on the grotesque body - wherein he states that the elements of the human face should be replaced by animal parts or objects in order to acquire that of the grotesque body. To reiterate, the "[human face] acquire[s] a grotesque character when they adopt the animal form or that of inanimate objects" (Bakhtin, 1984, p. 315). Here, what distinguishes the Whatsitsname from Bakhtin's interpretation is that the Whatsitsname is made solely of human body parts. Therefore, the grotesque image of Saadawi's Whatsitsname is more humane than that of Bakhtin's. Nevertheless, "[t]he grotesque body is not separated from the rest of the world. It is not a closed, completed unit; it is unfinished, outgrows itself, transgresses its own limits" (Bakhtin, 1984, p. 26). This characteristic of the grotesque body is adopted in the Whatsitsname's body: "He noticed the reflection of his own face in the glass. It rather surprised him-this was the first time he had recognized himself. He ran his finger over the stitches on his face and neck. He looked very ugly" (Saadawi, 2014, p. 55 [italics added]). Thus, this feature of the grotesque image in the Whatsitsname is compatible with Bakhtin's idea of it as "ugly [and] monstrous" (1984, p. 25). Yet, regardless of his appearance, the Whatsitsname is embraced by society.

Obviously, the Iraqi version of Frankenstein's monster carries out a new role, that of a leader and hero of ordinary people who seek justice. In the Whatsitsname's words: "I'm a savior, the one they were waiting for and hoped for in some sense ... The sinews of a law that isn't always on alert" (Saadawi, 2014 p. 142-43). Therefore, the monster is treated as a savior to remedy the situation in Iraq, as he has many followers who believe in him. He demands a reformation of the social and political situation in Iraq. The followers of the Whatsitsname are impressed with his ability to kill criminals and they continue to support him in his mission, seeing him as the hero who can potentially remedy the situation. The Whatsitsname, in turn, continues to kill criminals and mercenaries who are involved in escalating the violence. In his words, "I killed the al- Qaeda leader who lived in Abu Ghraib and who was responsible for the massive truck bomb in Tayaran Square that killed many people, including the person whose nose Hadi picked up off the pavement and used to fixed my face" (Saadawi, 2014, p. 153). Thus, he becomes an avenger for the people and himself.

Remarkably, the grotesque body of the Whatsitsname, who is assembled from the scattered body parts of the victims of violence in Iraq can be viewed as an analogy of the urgent need to unify Iraqi society and stop the sectarian violence and the terror that comes with it. According to Haytham Bahoora (2015, p. 189), "[t]he dismemberment of Iraqi bodies in fiction can be read as a metaphor for the viability of Iraq's cohesion and the possibility of its very national continuity." It is in the light of this that Saadawi uncovers a new meaning for the monster in terms of being part of a community, and what is more, being not only a representative of the Iraqi people but also a symbol for unity. 


\section{THE PURSUIT OF JUSTICE}

Justice and morality are fundamental concerns of humanity. Namely, they are the basis for establishing ideal relationships between the self and the Other, and they are essentially significant in human affairs. In this vein, Emmanuel Levinas offers a profound understanding of human relationships, vis a vis, the self and the Other, and the importance of justice in human existence. In fact, Levinas places a premium on the relationship between the self and the Other, wherein the Other occupies a place of great importance in respect to the self. That is to say, Levinas's thought is not restricted to the social obligation towards the Other but encompasses and transcends the ethical relation. To clarify, the question of justice is crucial, and it arises when there are three or more people involved, thereby to some extent changing the initial subjection of the self to the Other. In this sense, the self is still concerned with the good of the Other, but not exactly to the same degree. Thus, Levinas perceives the ethical responsibility towards the Other as a call to constitute a ground for justice. In his words: "Ultimately it is a question of founding the justice that offends the face on the obligation with respect to the face; the extraordinary exteriority" (Levinas, 1999, p.103). He suggests that ethic or ethical responsibility is the locus of justice.

To be more specific, Levinas's understanding of justice is based on subordination, as he puts it, "justice nonetheless marks a subordination of me to the other" (1999, p. 102). For him, "[t]he search for justice presupposes just such a new relation, in which all the excess of generosity that I must have toward the other is subordinated to a question of justice" (Levinas, 1999, p.102). This denotes that ethics precedes justice. To further illustrate this point, in ethics, the self is subject to the Other; the Other occupies a place of great importance. One is therefore responsible for the Other, even for his/her sins, even those against oneself. One must therefore forgive the Other. In terms of justice, however, things are more complicated; one cannot forgive a sin committed against someone other than oneself. In this context, justice enacts itself and is in turn enacted through interactions within human relations that are based on ethics. Therefore, the relation becomes more complicated, especially when justice is intertwined with ethics. In this situation, forgiveness might be required in a one-to-one relation, but it is not an option when three or more other people are involved. The oneself can forgive only to the self, but not on behalf of the Other. Simply put, forgiveness can take place on an individual level, but not on behalf of the Other.

The face of the Other calls for the establishment of justice in human affairs. Acceding to Levinas (1999, p. 294), "the face presents itself, and demands justice." This asserts that justice is a matter of obligation and subordination of the self to the Other. Based on Levinas's philosophical thought, the face of the Other cries for justice and the self has to respond, as it entails an absolute obligation. As per Levinasian's statement: "This is not owing to such and such a guilt which is really mine, or to offences that I would have committed; but because I am responsible for a total responsibility, which answers for all the others and for all in the others, even for their responsibility" (1985, p. 99). This parallels to Saadawi's creature, yet the latter is extreme. In other words, if we apply Levinas's notion of justice to the Whatsitsname, then he must forgive whoever killed him; yet, he cannot forgive those who killed the others who comprise his body. Justice means that the Whatsitsname cannot forgive someone who committed a crime against another person. In fact, if one person is wronged or has committed a crime, it becomes a responsibility to fight against the wrongdoer when it is required to be. In this scenario, the Whatsitsname incorporates Levinas's notion of justice.

This motive of justice applies to the Whatsitsname, as he proclaims, "I'm the answer to the call of the poor" (Saadawi, 2014, p. 142). At this point, Levinas and the Whatsitsname 
share the same principle (responsibility towards the Other) and demand the same object, justice. The position that Levinas holds by being ethically responsible for the Other in spite of the self, entails that the responsibility for the Other comes first in terms of his ethical approach. Therefore, it is a matter of priority and then subordination. As he explains, "[ $\mathrm{t}]$ he I always has one responsibility more than all the others" (1985, p. 98-99 [italics in the original]). In this vein, Levinas's account reveals a full consciousness of collective responsibility and a moral obligation to serve the Other by being there for the Other. Such a notion of collective responsibility is heavily embodied by the Whatsitsname's noble mission. In his words, "[i]n fact, there is a moral obligation to back me, to bring about justice in this world, which has been totally ravaged by greed, ambition, megalomania, and insatiable bloodlust" (Saadawi, 2014, p. 143 [italics mine]). Hence, for the Whatsitsname, the quest is not arbitrary, but it is a moral obligation and that is why he has accepted this responsibility, or rather, taken it upon himself to enact the justice of the people. This goes hand in hand with Levinas's argument: "Responsibility is what is incumbent on me exclusively ... [which] I cannot refuse" (Levinas, 1985, p. 101). By accepting his responsibility for the Other, Whatsitsname commits himself to unlimited obligations to serve the Other and deliver justice. In the Whatsitsname's words, "justice had to be done here on earth, with witness present" (Saadawi, 2014, p. 83). In this vein, the Whatsitsname's role can be seen as a vigilante figure who endeavors to enforce the law and achieve justice in the city of Baghdad where the legal and political authorities utterly fail to do so.

Indeed, the rise of the Whatsitsname can be viewed as a supernatural call of duty. In the Whatsitsname's words, "[t]he innards of the darkness moved and gave birth to me. I am the answer to their call for an end to injustice and for revenge on the guilty" (Saadawi, 2014, p. 143). Thus, the Whatsitsname is the hero for those innocent people who were murdered anonymously, as the Whatsitsname declares that: "With the help of God and of heaven, I will take revenge on all the criminals. I will finally bring about justice on earth, and there will no longer be a need to wait in agony for justice to come, in heaven or after death" (Saadawi, 2014, p. 143). Even if the Whatsitsname does not accomplish his mission, at least he will set an example for others, enabling them to continue along the same path; namely, the quest for just vengeance. In his words: "Will I fulfill my mission? I don't know, but I will at least try to set an example of vengeance - the vengeance of the innocent who have no protection other than the tremors of their souls as they pray to ward off death" (Saadawi, 2014, p. 143). Ergo, the Whatsitsname is oriented towards vengeance, as "a punishment that fits the crime."

Initially, the Whatsitsname commences his quest by seeking to enact retribution on those criminals who were responsible for killing the people from whom he is stitched together. But, gradually, the Whatsitsname expands his mission to include people who offend him as well. In the Whatsitsname's words: "I am now taking revenge on people who insult me, not just on those who did violence to those whose body parts I'm made of" (Saadawi, 2014, p. 185). In this manner, the Whatsitsname drifts progressively from his path, inasmuch as his sensibility affects his duty: That is potentially why he shifts further away from his ideals of justice and instead begins vengeance on those people who besmirch his name. He remarks that: "What's worse is that people have been giving me a bad reputation. They're accusing me of committing crimes, but what they don't understand is that I'm the only justice in this country" (Saadawi, 2014, p. 135). Here the Whatsitsname indirectly threatens those people who have accused him of being a criminal as opposed to a savior and their only hope of delivering justice: "They have turned me into a criminal and a monster" (Saadawi, 2014, p. 143). Therefore, they 
misunderstand his original mission - justice - and, accordingly, the Whatsitsname treats them as a target, insofar as he no longer tolerates them because of their accusations, which he dismisses as false.

Tragically, the monster's intention of consummating justice has been overwhelmed by the expansion of violence. As such, it speaks to Arendt's argument: "The danger of violence, even if it moves consciously within a nonextremist framework of short-term goals, will always be that the means overwhelm the end" (1970, p. 80). Hence, the Whatsitsname "eventually kills innocents too, reflecting the madness and moral ambiguities of the war and its aftermath" (Arango, 2014). Justifying his actions by saying that "[t]here are no innocents who are completely innocent or criminals who are completely criminal" (Saadawi, 2014, p. 214), the Whatsitsname threatens everybody, inasmuch as they are a legitimate target in his eyes. For him, there are no longer innocent people, according to his estimation. Therefore, the monster no longer distinguishes between right and wrong; between moral and immoral; between justice and injustice; between the victims and the criminals. Up to this point, the novel has employed a floating trope of Frankenstein's monster, and his journey is initially fascinating, bespeaking as it does a noble mission: justice. "He [the Whatsitsname] was on a noble mission and had to carry it out with as few complications as possible" (Saadawi, 2014, p. 132). At this point in the novel, Saadawi breaks with that pattern.

Here, the Whatsitsname loses sight of his original mission, as he recounts: "My list of people to seek revenge on grew longer as my old body parts fell off and my assistants added parts from my new victims, until one night I realized that under these circumstances I would face an open-ended list of targets that would never end" (Saadawi, 2014, p. 153). In this situation, the quest for justice is replaced by mere survival in such a dystopian world. This harkens to Hannah Arendt's statement: "The practice of violence, like all action, changes the world, but the most probable change is a more violent world" (1970, p. 80). Arendt suggests that violence triggers violence. This proposition confirms that violence generates monstrosity of the monster, as in the case of the Whatsitsname, wherein he is deeply immersed in keeping himself alive, but at the cost of the Other. Simply put, the monster no longer exists to serve the Other; rather, he devours the Other for his own existence. This is the point at which the monster departs from the path of justice, wherein he no longer cares for the Other, but only for himself. In this regard, the Whatsitsname loses his original quest of achieving justice by abandoned his responsibility for saving the Other. This aberration is what provokes the monster's monstrosity and thereby subverts his humanity. Instead of achieving justice and saving the Other, the monster is fed by violence and blinded by revenge. Therefore, he veers off from his original assignment, as his mission starts with justice and then is reoriented toward killing for the sake of surviving.vii Saadawi seems to be stressing the old maxim that violence only begets more violence, highlighting how violence dehumanizes not only the victims but the perpetrators as well, all of which is demonstrated by the Whatsitsname's actions.

Thus, this pursuit of justice changes its course and becomes the perversion of justice instead. Perhaps Saadawi sought to underscore a dark image of a society wherein the sense of justice is lost and people strive only to survive and disregard their responsibility towards the Other. The narrator emphasizes that, “because he was an exceptional killer who wouldn't die by traditional means, he thought he should exploit this distinctive talent in the service of the innocent - in the service of truth and justice. Until he was sure of his next steps, he would concentrate on ensuring his own survival" (Saadawi, 2014, p. 200-01). Saadawi seems to be 
suggesting that when a society fails to embrace the Other, it becomes a twisted and elitist one, pertaining an egocentric interest.

Needless to say, the Whatsitsname loses his perspective about truth and justice when he stops thinking about the Others and focuses on himself instead: "So he clung to life, may be more than others, more than those who gave him their lives and parts of their bodies" (Saadawi, 2014 , p. 267-68). This is where he turns into a monster, when pursuing a survival mode at the cost of the Others. Justice is about Others, which like ethics, requires a setting aside the self. The Whatsitsname is caught between the proverbial rock and a hard place: between survival, on the one hand, and accomplishing his mission on the other. Consequently, his monstrosity haunts him, interrupts his task, and thereby causes him to abandon his responsibility towards the Other. Saadawi's Frankenstein shows that when the monster loses his humanity, he murders his human side or spirit inside him and that is why his monstrosity overwhelms him. Put differently, instead of brining justice and saving humanity, the monster is conquered by his monstrosity and becomes guilty of his own actions.

\section{THE REPUBLIC OF VIOLENCE-BAGHDAD IN POST-2003}

It goes without saying that violence is a terrifying phenomenon and its consequences is even crueler in the ground. Violence can take many shapes and colors, including but not restricted to war and terrorism, and its effect, whether psychologically or physically, is brutal in every sense of the word. Human caused violence is a symptom of decay, inasmuch as it is an instrument of terror and destruction.viii That is to say, when law is misused, justice is lacking, and moral values are lost, violence arises from the heart of lawlessness and dominates the situation, as in the case of Baghdad after 2003. In the Iraqi context, violence becomes a present and lived reality. Consequently, violence is a product of local consumption of foreign materials of injustice, as it were.

In Saadawi's Frankenstein in Baghdad, he explores the pervasiveness of violence in Iraq, in post-2003 in terms of fear, terror, war, chaos, and destruction. "The very substance of violent action is ruled by the means-end category, whose chief characteristic, if applied to human affairs, has always been that the end is in danger of being overwhelmed by the means which it justifies and which are needed to reach it" (Arendt, 1969, p. 2). Even though violence is justified by its means, it is never legal.ix In other words, the absence of law, injustice, and presence of chaos naturally provide a fertile ground for violence. In this context, violence finds its place in the capital of Iraq, where people are dominated by fear and preoccupied with terrorism. Saadawi portrays an already macabre situation by means of still more grotesque techniques. He underscores the emergence of violence and terrorism that recrudesced in Baghdad via surreal imageries. As the narrator recounts, "when the Americans invaded Baghdad, their missiles destroyed the telephone exchange, and the phones were cut off for many months. Death stalked the city like the plague" (Saadawi, 2014, p. 6 [italics added]). By applying grotesque elements in his novel, Saadawi is able to capture a glimpse of quotidian reality in Iraq in post-2003.

Another important element that Saadawi uses to describe the spreading death in Baghdad is by means of gothic, as demonstrated in following scene: "as dead bodies littered the street like rubbish" (Saadawi, 2014, p. 153). As a result, people live in a constant fear, insofar as death becomes an everyday occurrence due to the explosion of violence in the city. Sadaawi's appeal to gothic offers him a wide space to register "the terrors of colonial [and sectarian] violence" that swept in his country, revealing the unspeakable through a gothic 
fashion (Bahoora, 2015, p. 191). Essentially, his narrative in utilizing this technique enables him to capture the aesthetics of horror-describing a dark reality with a colonial presence in the background. Although the author exaggerates in describing the real in delineating the gruesome scenes of death in the novel, he is able to highlight to the reader a sense of horror in a real world via gothic and surreal lenses, as in the following example: "There were bodies everywhere - on the street, on the sidewalk, some propped up against the walls, others slumped over balconies or piled at the entrances to the apartments or rooms" (Saadawi, 2014, p. 163). Such gothic scenes convey the dreadful atmosphere that haunts the city of Baghdad. By examining the Iraq situation through surreal lenses, Saadawi employs a gothic ink, highlighting the extreme forms of violence that are prevalent in Baghdad. In this regard, Sarah Perry argues, "[t]here are gothic elements but Saadawi is more concerned with capturing war as something surreal and pointless" (Perry, 2018).

Notably, violence has caused a general atmosphere of trepidation in the capital city of Iraq, wherein people are subject to death at any moment, and live in constant fear. As Saadawi notes, "[t]hings such as the lack of trust among people, the absence of law, the absence of security, increased fear" (Arango, 2014). Fear is the source of evil and wickedness in the country. Indeed, Saadawi is interested in conveying a sense of terror by applying gothic elements in his work. People are haunted by horror, as depicted by Saadawi. In his words, "[e]very day we're dying from the same fear of dying" (Saadawi, 2014, p. 123 [italics added]). This notion of fear is discussed extensively in the novel. For example, Farid Shawawaf, the journalist who works for al-Haqiqa, magazine proclaims, "Honestly, I think everyone was responsible in one way or another ... all the security incidents and the tragedies we're seeing stem from one thing - fear. The people on the bridge died because they were frightened of dying" (Saadawi, 2014, p. 123 [italics added]). Shawawaf continues by stating boldly that: "We are going to see more and more death because of fear" (Saadawi, 2014, p. 123). He goes further and urges, "[t]he government and the occupation force have to eliminate fear. They must put a stop to it if they want this cycle of killing to end" (Saadawi, 2014, p. 123). This suggests that it is a syndrome of fear that manifests as decay in Baghdad, and everyone has a part of the blame for such a horrific situation.

Unfortunately, instead of putting an end to the violence, the Whatsitsname eventually finds a justification for its proliferation, which is killing in order to survive. According to Arendt (1970, p. 51), "[v]iolence is by nature instrumental; like all means, it always stands in need of guidance and justification through the end it pursues." Arendt suggests that violence is a means that justifies its aims. That is, violence seeks to fulfil a specific end, which is haunted by its means according to what its justification entails. This argument aligns with the monster's justification for killing; as the narrator puts it, "he [the Whatsitsname] would salvage the spare parts he needed from the bodies of those who deserved to be killed. It wasn't the ideal option, but it was the best one possible for now" (Saadawi, 2014, p. 201). Clearly, Arendt posits a unilateral relation based on justification - violence as a means to justify the ends. However, Walter Benjamin's Critique of Violence (1921) perceives the notion of violence in a more holistic way; he postulates a bilateral or reciprocal relation between means and ends. While Benjamin partly agrees with Arendt in terms of how violence relies on its unilateral relation as a means to justify an end, Benjamin's perspective goes further and reverts the violence's formula to an opposite relation. In other words, violence stems from both means and ends and any criticism of violence on the basis of the two concepts together is fertile, inasmuch as any critique of violence has to include a profound analysis of both concepts: ends and means. In 
Benjamin's words: "The task of a critique of violence can be summarized as that of expounding its relation to law and justice. For a cause, however effective, becomes violent, in the precise sense of the word, only when it bears on moral issues" (1986, p. 277). He elaborates by stating that "just ends can be attained by justified means, justified means used for just ends" (1986, p. 293). Benjamin suggests that violence pertains to law and justice, as both means and ends. In this light, the Whatsitsname appears to embody Arendt's notion of violence, as discussed above.

The political situation is unstable in Iraq because of the state of war and violence, so any step towards stability has to stop the violence at its root. In Saadawi's novel, despite the existence of the Iraqi government, the Tracking and Pursuit Department, headed by the Brigadier Majid, who is actually appointed by the American collation authority, and the presence of the American army, no one is able to stop the violence. Sadly, however, even Saadawi's monster seems unable to end the violence. In Saadawi's words, "I am trying to bring together all of the elements of the Iraqi experience," wherein "there are many messages. One of them is that with this war and violence, no one is innocent" (Arango, 2014 [italics added]). In this statement, Saadawi blames everybody for the present situation in Iraq and holds them accountable for such a tumultuous state.

What distinguishes Saadawi's Frankenstein in Baghdad is using various strategies, including the fantastic, the grotesque, and the gothic to create not only his monster but also to reflect the dystopian elements that are predominant in the city of Baghdad. Therefore, Saadawi's fictional writing reveals a powerful sense of aesthetic expression in protesting violence in his birth city, Baghdad. His artistic ability allows him to accomplish a leap of creative imagination, capturing the sense of pandemonium that prevails in Baghdad in the aftermath of 2003. That is why he was awarded the IPAF in 2014.x

Interestingly, the novel is not about the monster or Hadi per se, nor the monstrosity that haunts the monster towards the end of his quest, but rather, the real monster of Baghdad is the unleashed violence that broke out in Saadawi's city of birth, Baghdad, after 2003. More importantly, Saadawi holds everyone responsible for such a dystopian state in the country, and it is everyone's task to remedy the situation by stopping the violence, calling for unity, restoring law, and achieving justice.

\section{CONCLUSION}

In short, the novel is indeed built upon the metaphor of Frankenstein's monster, however Saadawi establishes a nobler mission for his monster_to pursue justice. Firstly, Baghdad can be seen as a trial court for the guilty and a coffin for the criminals because of the Whatsitsname's actions. Nonetheless, Saadawi fails to maintain the ethics of the Whatsitsname, who, when overwhelmed by violence, loses his morality and humanity_he no longer distinguishes between innocence and guilt. What brings the monster down is the monstrosity of violence in Baghdad and the abandonment of his responsibility towards the Other, due to his desire to catch his own breath (clinging to life by devouring the Other), even at the cost of killing the Others, whether they are criminal or innocent. Unfortunately, the quest for justice is lost in the abyss. Thus, the monster manifests monstrosity instead of nobility. Perhaps the author deliberately attempts to exhibit how a loss of ethics results in rack and ruin a breakdown. And yet, much of the significance that can be drawn from Frankenstein's metaphor in Saadawi's novel lies in his demonstration of the two sides of the monster-his humanity and his monstrosity. The Whatsitsname's humanity calls on him to save the Other and restore law 
and justice in the city of Baghdad, while his monstrous actions signify the vehement situation in Iraq, which is characterized by political corruption, a lack of justice, chaos, terror, and violence.

More fundamentally, Saadawi gives Frankenstein in Baghdad a role in Iraqi society by being the novel representative of the Other, questioning the issue of identity, urging people to unify, and to put an end to the violence. All in all, one of the most important messages of Frankenstein in Baghdad is that violence causes the fragmentation of society, which has emerged because of the state of occupation and war, while unity, justice, and collective responsibility give meaning to life and save humanity. In its totality, Saadawi's novel altogether remains as a protest against existing conditions, where violence is denounced, unity is needed, justice is pursed, and freedom is demanded.

\section{REFERENCES}

Al-Qarawee, H. (2014, September 28). Reading 'Frankenstein in Baghdad.' Al-Monitor. Retrieved February 04, 2020 from www.al-monitor.com/pulse/originals/2014/03/iraqliterature-address-political-violence.html

Allen, R. M. (1993) “The Mature Arabic Novel Outside Egypt.” In M. M. Badawi (Ed.), Modern Arabic Literature (pp. 193-222). Cambridge University Press, Cambridge.

Arango, T. (2014, May 16). Baghdad Is a Setting, and a Character, Too. New York Times. Retrieved January 21, 2020, from http://www.nytimes.com/2014/05/17/world/middleeast/iraqi-novelist-dodging-bombswrites-to-clear-the-fog-of-war.html

Arendt, H. (1969). Reflections on Violence. Journal of International Affairs, 23(1), 1-35. Retrieved January 21, 2020, from www.jstor.org/stable/24356590.

Arendt, H. (1970). On violence. New York: Harcourt, Brace \& World.

Bahoora, H. (2015). Writing the Dismembered Nation: The Aesthetics of Horror in Iraqi Narratives of War. The Arab Studies Journal, 23(1), 184-208. Retrieved February 5, 2020, from www.jstor.org/stable/44744904

Bakhtin, M. (1984). Rabelais and his world (1st Midland book ed.). Bloomington: Indiana University Press.

Becker, E. M. B. (2018, May 21). 2018 Man Booker International Prize Q\&A-Ahmed Saadawi. Retrieved January 21, 2020, from https://www.wordswithoutborders.org/dispatches/article/2018-man-booker-internationalprize-qa-ahmed-saadawi-eric-m-b-becker

Benjamin, W., \& Jephcott. E. (1986) “Critique of Violence.” In Peter Demetz (Ed.), Reflections: Essays, Aphorisms, Autobiographical Writing (pp. 277-300). New York: Schocken Books.

East, B. (2018, February 6). 'Frankenstein In Baghdad' to be released in English: we speak to Ahmed Saadawi. The National. Retrieved January 21, 2020, from http://www.thenational.ae/arts-culture/frankenstein-in-baghdad-to-be-released-in-englishwe-speak-to-ahmed-saadawi-1.702127

Elayyan, H. (2017). The Monster Unleashed: Iraq's Horrors of Everyday Life in Frankenstein in Baghdad. AWEJ for translation \& Literary Studies, 1(1) 158-170. 
Freud, S., McLintock, D., \& Haughton, H. (2003). The uncanny. New York: Penguin Books.

Hankir, Z. (2018, June 19). Ahmed Saadawi Wants to Tell a New Story About the War in Iraq. Retrieved January 21, 2020, from https://lithub.com/ahmed-saadawi-wants-to-tell-a-newstory-about-the-war-in-iraq/

Introduction: Iraqi Fiction Today. (2008). In Mustafa S. (Ed.), Contemporary Iraqi Fiction: An Anthology (pp. Xiii-Xxii). Syracuse, New York: Syracuse University Press. Retrieved January 21, 2020, from www.jstor.org/stable/j.ctt20p5795.4

Kowalewski, M. (1993). INTRODUCTION: Reading Violence, Making Sense. In Deadly Musings: Violence and Verbal Form in American Fiction (pp. 3-24). PRINCETON, NEW JERSEY: Princeton University Press. Retrieved January 21, 2020, from www.jstor.org/stable/j.ctt7t583.4

Lévinas, E. (1999). Alterity and transcendence. New York: Columbia University Press.

Lévinas, E., \& Nemo, P. (1985). Ethics and infinity. Pittsburgh: Duquesne University Press.

Lévinas, E., \& Lingis, A. (1995). Totality and infinity: an essay on exteriority. Pittsburgh: Duquesne University Press.

Mbembe, A. (2001). On the Postcolony. (1st ed.). University of California Press. JSTOR. Retrieved from www.jstor.org/stable/10.1525/j.ctt1ppkxs

Mohammed, S.R. (2018). The Return of Scheherazade, or the Rise of the Iraqi Novel after 2003. World Literature Today, 92(2), 32-36. doi:10.7588/worllitetoda.92.2.0032

Najjar, A.-M. (2014, April 30). 'Baghdad Writes!' ArabLit Quarterly. Retrieved January 21, 2020, from https://arablit.org/2014/04/30/Baghdad-writes/

Perry, S. (2018, February 16). Frankenstein in Baghdad by Ahmed Saadawi review - strange, violent and wickedly funny. Retrieved January 21, 2020, from http://www.theguardian.com/books/2018/feb/16/frankenstein-in-baghdad-by-ahmedsaadawi-review

Saadawi, A. (2014, March 26). Iraqi Author Ahmad Saadawi: 'The Novel Implicitly Questions This Concept of Salvation.' By Al-Mustafa Najjar. ArabLit Quarterly. Retrieved February 04, 2020, from arablit.org/2014/03/26/iraqi-author-ahmad-saadawi-the-novel-implicitlyquestions-this-concept-of-salvation/

Saadaawi, A., \& Wright, J. (2018). Frankenstein in Baghdad: a novel. New York: Penguin Books.

Shelley, M., \& Crook, N. (1996). Frankenstein, or, The modern Prometheus. London: W. Pickering.

Vieira, F. (2010) “The concept of utopia.” In Gregory Claeys (Ed.), The Cambridge Companion to Utopian Literature (pp. 3-27). Cambridge University Press.

Webster, A. (2018). Ahmed Saadawi's Frankenstein in Baghdad: A Tale of Biomedical Salvation? Literature and Medicine, 36, 439 - 463. 
i In his interview on "Words without Borders," Saadawi states that "I have strong ties to the Arab tradition of narrative in both its artistic and historical forms. In its artistic form it appears in Kalila and Dimna, A Thousand and One Nights, and folk stories that were transmitted orally. As for the historical form, I treat classical historical writings in Arabic as narrative texts. Although they claim to address real events, they are full of miraculous events and mythical and metaphysical stories" (Becker, 2014). This denotes that Saadawi longs for his literary heritage, which in turn, inspires his writing.

ii The Whatsitsname informs Hadi that "the soul of Hasib Mohamed Jaafar was demanding revenge" (Saadawi, 2014, p. 129).

iii “The New York Times," 16 May 2014.

iv Interview with Ahmed Saadawi by Eric M. B. Becker, Words without Borders 2018 (E2018 Man Booker International Prize Q\&A-Ahmed Saadawi).

"For Saasawi, "[t]he job of the writer is to give a voice to unknown people," he stresses, "I have a strong sense of belonging to this city, and I will continue writing about humanity through the stories of the individuals I meet in Baghdad" (Hankir, 2018).

${ }^{v i}$ In his interview in Al-Monitor, Saadawi explains that "[f]antasy is not an escape or alienation from reality. It is rather a way to reach greater depth in this reality, which is packed with fantasy as a daily behavioral and rhetoric practice" (al-Qarawe, 2014).

${ }^{\text {vii }}$ In the same vein, Webster argues, "Like the soldiers who fought in Iraq, the Whatsitsname at first claims his acts of violence were justified as a means of humanitarian intervention that would ultimately save the lives of others, yet when he falls victim to this cycle of destruction himself, his focus shifts to his own survival. He abandons those who he claimed to be helping to the violence left in his wake, exposing the material consequences of a destroy-and-build logic: the destruction of many and the rebuilding, or regeneration, of a select few" (2018, p. 458).

viii In his Deadly Musings, Michael Kowalewski conceives violence "as an act of aggression that is usually destructive, antisocial, and degrading in its consequences and that usually seems deliberate" (1993, p. 6).

ix As Arendt argues, "[v]iolence can be justifiable, but it never will be legitimate" (1970, p. 52).

x The committee's remarks regarding Ahmed Saadawi's Frankenstein in Baghdad: "The novel was selected for the prize due to ... the creativity in the narrative structure, especially in the portrayal of the character of al-Shesma [the main character]. This character sums up a type and a level of violence that has infected Iraq, the Arab countries, and, indeed, the whole world in recent days. It also contains various levels of well-written, multifaceted narrative. For this and many other reasons, it constitutes an important contribution to contemporary Arab novelistic writing" (Sadek, 2018, p. 36).

\section{$\underline{A U T H O R ' S ~ B I O:}$}

Rawad Alhashmi is a Ph.D. candidate and an instructor of rhetoric at the University of Texas at Dallas. He is also a translator. His research interests include modern translation, world literature, postcolonial theories, and speculative fiction. 